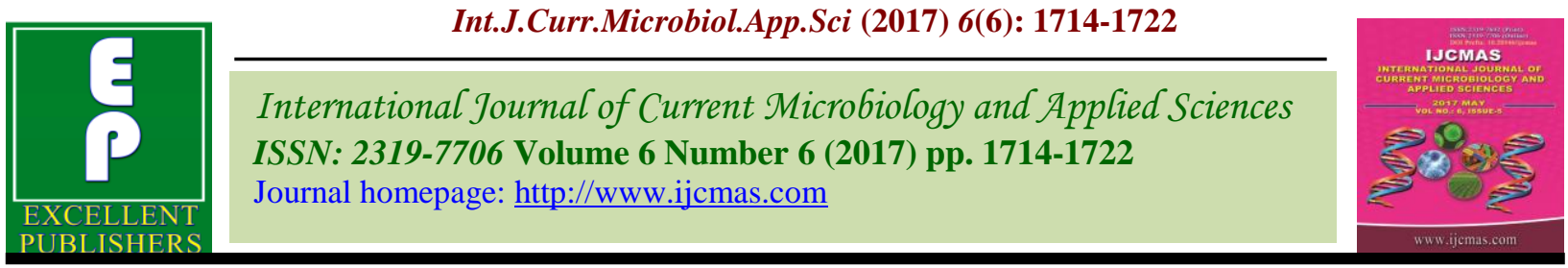

Original Research Article

https://doi.org/10.20546/ijcmas.2017.606.199

\title{
Cloning and Transformation of Engineered Bougainvillea Antiviral Gene in Tomato Plant
}

\author{
Mayur R. Wallalwar* and R. Balasaraswathi \\ Department of Plant Biotechnology, Centre of Plant Molecular Biology and Biotechnology, \\ Tamil Nadu Agricultural University, Lawley Road, Coimbatore 641 003, India \\ *Corresponding author
}

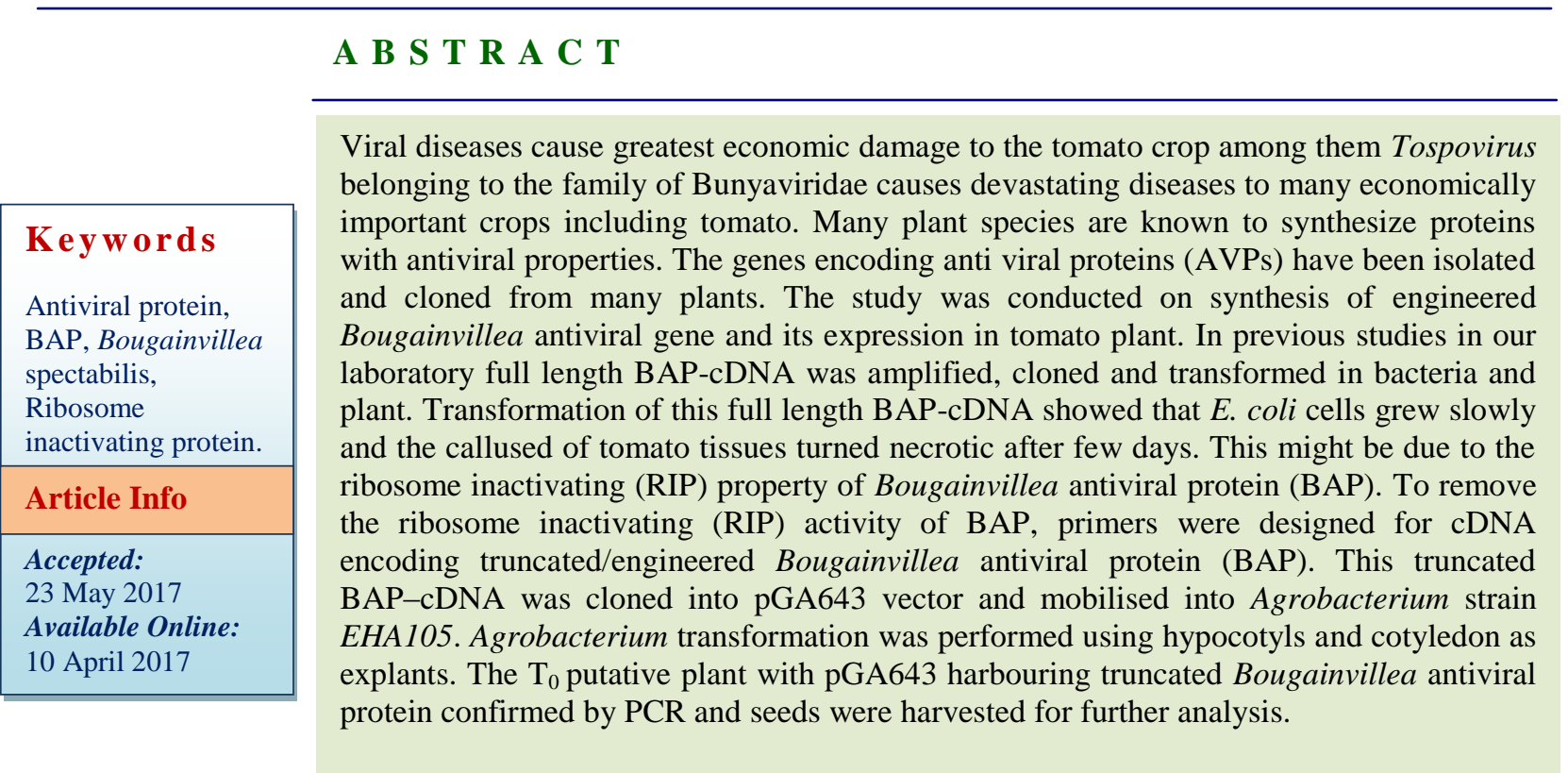

\section{Introduction}

Tomato (Solanum lycopersicum L.) is one of the major vegetables grown worldwide, either for fresh fruits or for processing. India contributes 11 per cent of world's total tomato production. It is grown on an area of $8,70,000$ ha with average productivity of $20.1 \mathrm{MT} / \mathrm{ha}$ during 2011-12 (FAO Statistical Database, 2013). Plant protection against biotic stress is indispensable to increase agriculture production. In general it was estimated that crop diseases causes major losses which are estimated to be $14 \%$ of total agricultural production (Carlton et al., 2012).
Among all plant diseases, viral diseases are found to be of immense importance considering the extensive damage and causes severe losses to the crops (Sastry et al., 2013). It was reported that under epidemic condition viral disease alone can cause $90 \%$ crop losses in certain crops (Rosello et al., 1996). Unlike fungal or bacterial pathogens, viruses cannot be controlled by chemical pesticides. Tospovirus belonging to the family of Bunyaviridae encompasses the group of viruses that causes devastating diseases to many economically important crops including 
tomato (Peters et al., 2003). Infection by tospovirus at early stages of plant growth causes utmost damage, often resulting in severe stunting of the entire plant that ultimately may lead to death (Smith et al., 2006).

Certain plant species are known to synthesize proteins with antiviral properties and viral inhibitors are well studied in Phytolacca americana (PAP), Dianthus caryophyllus (Dianthin), Mirabilis jalapa (MAP) and Bougainvillea spectabilis (BAP) (Irvin, 1975; Stirpe et al., 1981; Kubo et al., 1990; Balasaraswathi et al., 1998). These proteins belong to a family of ribosome inactivating proteins (RIPs), which directly inhibit the protein synthesis on ribosomes. Bougainvillea spectabilis Willd. is an ornamental plant belonging to the family Nyctaginaceae. The crude leaf/root extract of Bougainvillea spectabilis Willd. was effective in inhibition of several plant viruses viz., tospoviruses, tobacco mosaic virus, cowpea aphid borne mosaic virus and cucumber mosaic virus (Balasaraswathi et al., 1998; Sadasivam et al., 1991). The virus inhibitor in B. spectabilis was found to be a Bougainvillea antiviral protein (BAP). The protein was purified to homogeneity and characterized from roots of B. spectabilis (Balasaraswathi et al., 1998). BAP was also found to be a ribosome in activating protein (RIP) (Murugan, 1999) and was very effective in inhibition of tospoviruses.

The full length BAP-cDNA was isolated from Bougainvillea spectabilis and cloned in bacterial and plant transformation vector and it was expressed in E. coli and tomato leaf explants respectively. Transformation showed that E.coli cells grew slowly and transformed tomato tissues callused but it turned necrotic after few days. This might be due to the ribosome inactivating (RIP) property of Bougainvillea antiviral protein (BAP). The cytotoxicity of pokeweed antiviral protein
(PAP) was reduced by engineering the corresponding gene (Tumer et al., 1997). In the present study, synthesis of truncated/engineered BAP-cDNA to reduce/remove cytotoxicity, still retaining the antiviral activity of Bougainvillea antiviral protein; construction of plant transformation vector harbouring engineered BAP-cDNA along with transformation of tomato plant using constructed vector was planned.

\section{Materials and Methods}

\section{Materials}

Mature leaves of Bougainvillea spectabilis Willd. were collected from Botanical Gardens, Tamil Nadu Agricultural University campus, Coimbatore. Seeds of tomato $c v$., PKM1 were obtained from Horticulture College and Research Institute, Periyakulam.

\section{Isolation of RNA and synthesis of cDNA encoding BAP}

Total RNA was isolated from mature bougainvillea spectabilis leaves (100 mg) using ONE STEP RNA reagent $(\mathrm{M} / \mathrm{s}$ Bio Basic Inc., Canada). The purity of the isolated RNA was checked using spectrophotometer. The isolated RNA was dissolved in nucleasefree water and stored at $-80^{\circ} \mathrm{C}$ until further use. First-strand cDNA was synthesized as per the manufacturer's protocol (Revert Aid $^{\mathrm{TM}}$ Premium First Strand cDNA synthesis Kit, Fermentas). Second strand full length and truncated BAP-cDNA were synthesized using already designed primers in our lab. The thermocyclic conditions for amplification of BAP consist of $5 \mathrm{~min}$ at $95^{\circ} \mathrm{C}$ for initial denauration, 35 cycles, $40 \mathrm{sec}$ at $94^{\circ} \mathrm{C}, 40 \mathrm{sec}$ at $53.6^{\circ} \mathrm{C}$ of annealing and $1 \mathrm{~min}$ at $72^{\circ} \mathrm{C}$ followed by $5 \mathrm{~min}$ at $72^{\circ} \mathrm{C}$ as final extension for truncated BAP-cDNA. The PCR products were analysed on $1 \%$ agarose gels. Synthesized cDNA were cloned into pTZ57R/T vector (InsTA cloning Kit). E. 
coli, DH5 $\alpha$ competent cells were transformed with the clone and the positive clones were confirmed by colony PCR and restriction digestion. The positive clones were sequenced and confirmed (Eurofins Genomics India PVT LTD, Banglore).

\section{Construction of plant expression vector}

The pTZ vector harbouring truncated BAPcDNA and empty plant transformation vector, pGA643 were cut with $B g l \mathrm{II}$ and $\mathrm{XbaI}$ restriction enzymes, the released fragment of $\sim 750 \mathrm{bp}$ was purified and cloned into $\mathrm{Bg} / \mathrm{II}$ and $\mathrm{XbaI}$ sites ofpGA643 vector between CaMV promoter and gene7 terminator. After transformation in E. coli, DH5 $\alpha$, the positive clones were confirmed by colony PCR, followed by restriction digestion with $B g l \mathrm{II}$ and XbaI.

\section{Mobilisation of plant transformation vector in Agrobacterium tumefaciens}

The positive clone were mobilized in to Agrobacterium strain (EHA105) with help of Helper strain(pRK2013) and E. coli strain (DH5 $\alpha)$ harbouring vector harbouring truncated BAP-cDNA as donar by tri-parental mating. The positive Agrobacterium colonies were confirmed by using colony PCR with help of gene specific primers and vir gene primers which was further confirmed by back transformation.

\section{In vitro seed germination}

Half strength MS medium is used for seed (PKM1) germination in tissue culture room. To generate explant material, seeds of Solanum lycopersicum var. PKM1 were washed in sterile water 2-3 times. Seeds were then surface-sterilized with $70 \%$ ethanol (1-2 min), followed by $4 \%$ sodium hypochlorite solution with intermittent shaking (2-3 min), followed by $4-6$ washes with sterile water.

\section{Pre-culture and co-cultivation}

Cotyledonary and hypocotyl explants of $c v$., PKM1 collected from in vitro grown 10 to 12 day-old seedlings were excised and placed on preculture medium (MSB5 medium +1.0 $\mathrm{mgl}^{-1}$ Zeatin) for 2-3 days prior to cocultivation in dark. From plate containing Agrobacterium tumefaciens strain, EHA105 harbouring the gene construct (pGA643truncated BAP-cDNA), a loopful of culture was inoculated into $5 \mathrm{ml}$ of YEP broth containing of tetracyclin and rifampicin as selective agent and incubated at $28^{\circ} \mathrm{C}$ with shaking at $180 \mathrm{rpm}$. From an overnight culture, $1 \mathrm{ml}$ culture was transferred into 30 $\mathrm{ml}$ of YEP broth containing the same selective agents. The 6-8 hrs grown culture was harvested by centrifugation at $3000 \mathrm{rpm}$ for $7 \mathrm{~min}$. For co-cultivation of explant, the pellet was resuspended in $30 \mathrm{ml}$ of MS broth, containing $100 \mu \mathrm{M}$ acetosyringone. Two to three days old explants from precultured plate were carefully submerged in the Agrobacterium suspension $(30 \mathrm{ml}$ of $\mathrm{MS}$ broth $+100 \mu \mathrm{M}$ acetosyringone) in a sterile Petri plate for 10-12 min with gentle swirling. The excess bacterial suspension was removed by blot drying with sterile filter paper and transferred to co-cultivation medium (Modified MS medium + $1.0 \mathrm{mgl}^{-1}$ zeatiin + $100 \mu \mathrm{M}$ acetosyringone). The explants were washed after 48 hours of co-cultivation in the dark at $25^{\circ} \mathrm{C} \pm 2{ }^{\circ} \mathrm{C}$ with sterile distilled water and with an aqueous solution containing 250 $\mathrm{mgl}^{-1}$ of cefotaxime followed by two washes with sterile distilled water.

\section{Selection and regeneration}

After final washing, the co-cultivated explants were blot dried on sterile filter paper and cultured on the selection medium (Modified $\mathrm{MS}$ medium $+0.5 \mathrm{mgl}^{-1}$ zeatin $+2.0 \mathrm{mgl}^{-1} 2,4-$ $\mathrm{D}+50 \mathrm{mgl}^{-1}$ kanamycin $+250 \mathrm{mgl}^{-1}$ cefotaxime). The explants were sub cultured 
on the same medium at 15 to 20 days interval. Calli obtained from co-cultivated explants were transferred on shoot regeneration medium (Modified MS medium $+2.0 \mathrm{mgl}^{-1}$ zeatin $+50 \mathrm{mgl}^{-1}$ kanamycin $+250 \mathrm{mgl}^{-1}$ cefotaxime) and remaining calli were subcultured on fresh regeneration medium every 15 days interval. The well developed shoots were transferred to rooting medium (half strength of Modified MS without hormone). In addition cefotaxime $\left(250 \mathrm{mgl}^{-1}\right)$ and kanamycin $\left(30 \mathrm{mgl}^{-1}\right)$ were added to maintain putative transformants.

\section{Molecular analysis of transgenic plants}

The presence of truncated BAP-cDNA transgenes in putative transformants was confirmed by PCR. For PCR, DNA was isolated from leaf $(50-100 \mathrm{mg})$ using C-TAB method. For each PCR reaction, $100 \mathrm{ng}$ of this DNA preparation was used as a template. The reaction for each putative transformants was prepared separately. Amplified products were analyzed by gel electrophoresis on $1 \%$ agarose gel.

\section{Results and Discussion}

\section{Isolation and synthesis of second strand} cDNA

The RNA obtained from the leaf tissues of $B$. spectabilis Wild was intact as seen in $1 \%$ agarose gel electrophoresis. It was reverse transcribed into first strand cDNA using RTPCR. With help of gene specific primer truncated BAP-cDNA were obtained. The truncated cDNA sequence was found to be $\sim 750$ bp long (Fig. 1).

\section{Construction of plant transformation vector}

Positive transformants having truncated cDNA in pTZ57R/T vector were confirmed colony PCR. Recombinant plasmid were digested with $B g l I I$ and $X b a I$. The released cloned fragment of $~ 750$ bpconfirmed our insert.Plasmid was sequenced by automated sequencing method and showed $84 \%$ identity, confirming that it is truncated BAP-cDNA clone. Positive transformants harbouring truncated cDNA in pGA643 were confirmed by colony PCR and restriction digestion confirms cDNA fragment of $\sim 750$ bp in plant transformation vector (Fig. 2).

\section{Mobilization of plant transformation vector}

Recombinant colonies of Agrobacterium strain were confirmed on selective media containing tetracyclin and rifampicin using colony PCR. Plasmid constructs were further checked and confirmed for the presence of engineered BAP-cDNA by using back transformation and restriction digestion along with PCR.

\section{Transformation of plants}

In the present study the better germination percentage and reduced time span for germination was observed, when sodium hypochlorite was used for seed sterilization compared with mercuric chloride. Pawar et al., (2012) reported that sodium hypochlorite was found better for seed sterilization as synchronous and high seed germination percentage was observed. When mercuric chloride was used, there was decrease in seed germination and it was not synchronous. $\mathrm{Wu}$ et al., (2011) also found that sodium hypochlorite is better than mercuric chloride for tomato seed disinfection.

A total of 100 each of cotyledonary and hypocotyl explants (Fig. 3A) were cocultivated with A. tumefaciensstrain EHA105 harbouring pGA643-truncated BAPcDNA. 


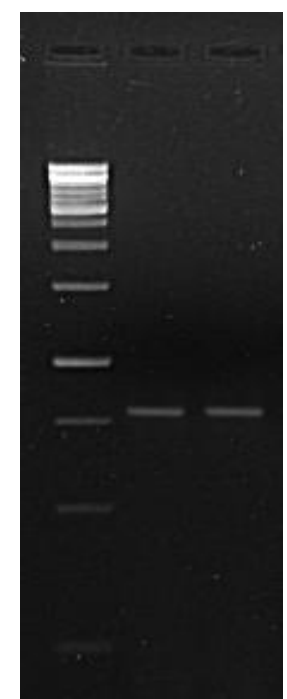

Fig.1 Second strand cDNA. M - 1 kb ladder, L1, L2 - truncated BAP-cDNA

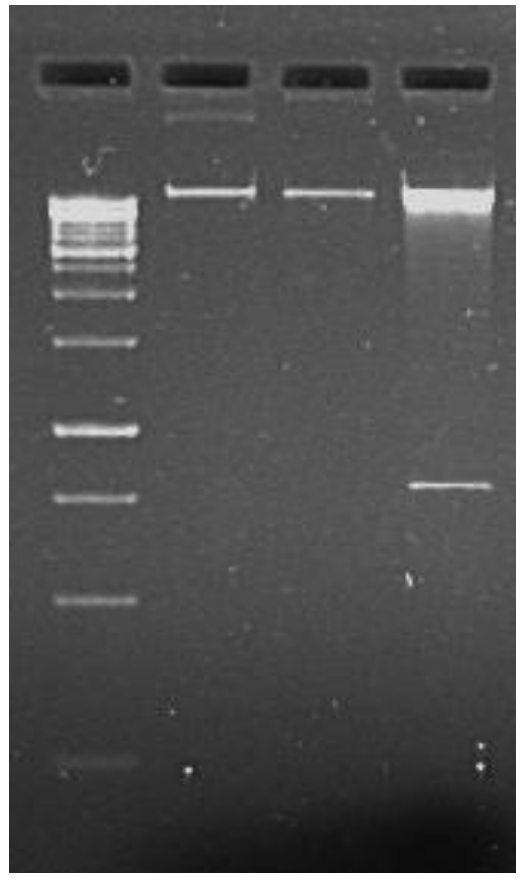

Fig.2 Restriction digestion of recombinant plasmid.M-1 kb ladder, L1 -Recombinant pGA643 truncated BAP-cDNA vector, L2- XbaI digested recombinant vector, L3-BglII and XbaI digested recombinant vector 


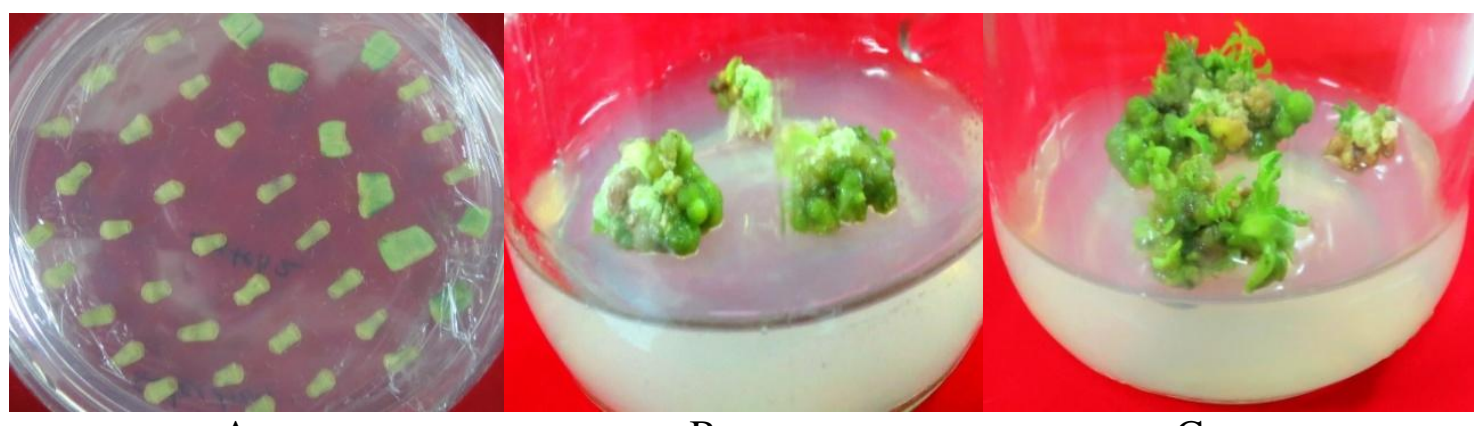

A

B

C

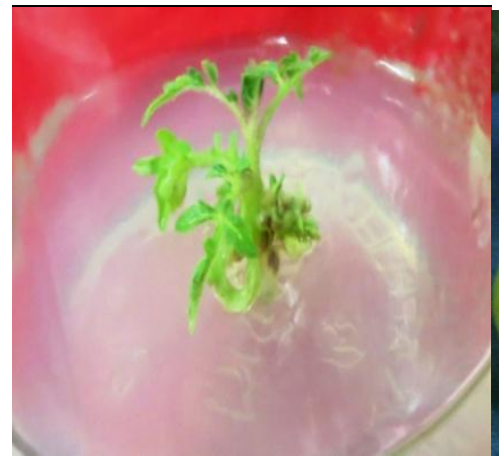

$\mathrm{D}$

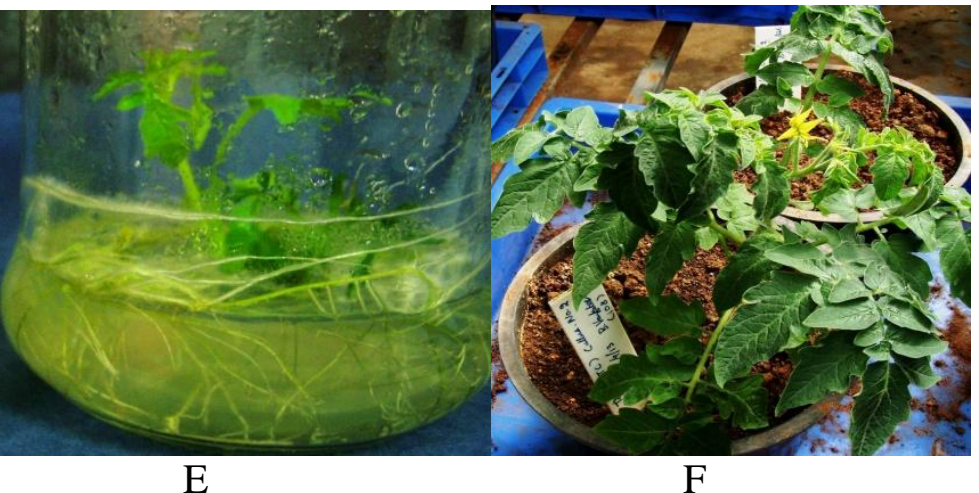

Fig.3 Plant transformation with Agrobactrium strain harbouring pGA643-truncated BAP-cDNA. A- explant co-cultivated with Agrobactrium strain harbouring pGA643-truncated BAP-cDNA on slection medium. B- Calli obtained from co-cultivated explant. C -Calli on the shooting medium. D- Shoot seperated placed on rooting medium. E- Regenerated plant with functional shoot and root in culture medium. F- Complete plant in green house.

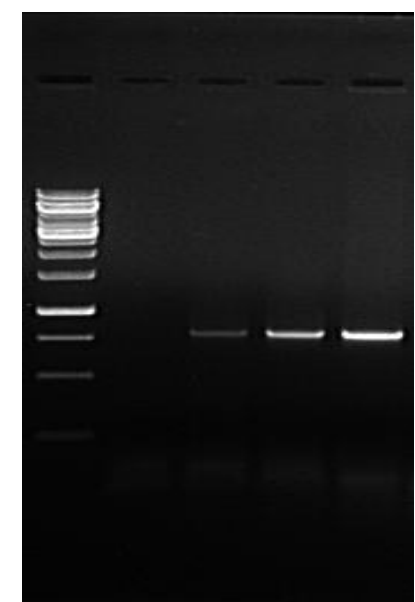

Fig.4 PCR analysis Three $\mathrm{T}_{0}$ putative transformants of tomato plants transformed with pGA643truncated BAP-cDNA (TBAP-cDNA) construct. M-1 kb ladder L1- Negative control. L2,L3 Sample of $\mathrm{T}_{0}$ putative plants. L4- Positive control 
After two rounds of selection, 32 kanamycin resistant calli were obtained from the cocultivated cotyledonary and hypocotyl explants (Fig. 3B). These calli were then transferred to shooting medium for 15-20 days (Fig. 3C). After shoots formation, shoots detached from calliwere transferred to rooting medium (Fig. 3D).

The complete rooted plants obtained after 15 days (Fig. 3E) were primary hardened and transferred in green house for futher studies (Fig. 3F). Most published protocols for tomato transformation (Ellul et al., 2003; Vidya et al., 2000; Hamza and Chupeau, 1993) describe cocultivation of the explants with various Agrobacterium strains (LBA4404, EHA105, GV311SE or A208) for 48 hours with variable bacterial densities.

In the present study the Agrobacterium strain, EHA105 was used to co-cultivate the cotyledonary and hypocotylary explants of the, $c v$. PKM1 tomato variety and cocultivation was carried out up to 48 hours using EHA105 harbouring pGA643(truncated BAP-cDNA) construct. In the present study, Solanum lycopersicon $c v$., PMK1 plants transformed using A. tumefaciens harbouring pGA643 with truncated BAP-cDNA.Oktem et al. (1999) observed that transformation frequency showed drastic variations according to explant type (cotyledon, hypocotyls or leaf pieces) and Agrobacterium tumefaciens strain (LBA4404 or EHA105). Transformation experiments with LBA4404 hypocotyl combination revealed no kanamycin-resistant calli and LBA4404 leaf piece combination resulted with no success. While using 8-14 days old cotyledonary explants and pGUSINT harbouring supervirulent Agrobacterium tumefaciens EHA105 strains, obtained kanamycinresistant callus and shoot formation in tomato $c v ., \mathrm{WC} 156$.
Molecular analysis of putative $\mathbf{T}_{0}$ transgenic tomato lines

PCR analysis with DNA isolated from three $\mathrm{T}_{0}$ putative transformants of tomato plants transformed with pGA643-truncated BAPcDNA construct were found to be positive for gene of interest. It showed an expected amplicon size of $\sim 750 \mathrm{bp}$ (Fig. 4).

The transformants obtained will be further confirmed by sourthen blotting for gene integration/copy no. and western blotting for protein expression. Plant obtained truncated constructs were checked for Tospovirus resistance.

\section{Acknowledgements}

The authoris thankful to the Department of Biotechnology, New Delhi for awarding a research fellowship for current study.

\section{References}

Balasaraswathi, R., S. Sadasivam, M. Ward and J. Walker, 1998. An antiviral protein from bougainvillea spectabilis roots; purification and characterisation. Phytochemistry. 47: 1561-1565.

Balasubramanian, S. and P. Palanivelu, 2011. Molecular cloning and expression of a phytase gene from the thermophilic fungus, Thermomyces lanuginosus-rmb. Journal of Phytology. 3:

Carlton, R. R., J. S. West, P. Smith and B. D. Fitt, 2012. A comparison of ghg emissions from UK field crop production under selected arable systems with reference to disease control. European journal of plant pathology. 133: 333-351.

Cho, H.-J., S.-J. Lee, S. Kim and B.-D. Kim, 2000. Isolation and characterization of cDNAs encoding ribosome inactivating protein from Dianthus sinensis 1 . 
Molecules and cells. 10: 135-141.

CONCANAVALIN, A., 1980. Gelonin, a new inhibitor of protein synthesis, nontoxic to intact cells.

Ellul, P., B. Garcia-Sogo, B. Pineda, G. Rios, L. Roig and V. Moreno, 2003. The ploidy level of transgenic plants in Agrobacterium-mediated transformation of tomato cotyledons (Lycopersicon esculentum 1. Mill.) is genotype and procedure dependent. Theoretical and Applied Genetics. 106: 231-238.

FAO Statistical Database (2012) FAOSTAT Agriculture data, URL, http://faostat.fao.org/site

German, T. L., D. E. Ullman and J. W. Moyer, 1992. Tospoviruses: Diagnosis, molecular biology, phylogeny, and vector relationships. Annual review of phytopathology. 30: 315-348.

Habuka, N., Y. Murakami, M. Noma, T. Kudo and K. Horikoshi, 1989. Amino acid sequence of mirabilis antiviral protein, total synthesis of its gene and expression in Escherichia coli. Journal of Biological Chemistry. 264: 66296637.

HAMZA, S. and Y. CHUPEAU, 1993. Reevaluation of conditions for plant regeneration and Agrobacteriummediated transformation from tomato (Lycopersicon esculentum). Journal of Experimental Botany. 44: 1837-1845.

Irvin, J. D., 1975. Purification and partial characterization of the antiviral protein from Phytolacca americana which inhibits eukaryotic protein synthesis. Archives of biochemistry and biophysics. 169: 522-528.

Jones, R. and M. Sharman, 2005. Capsicum chlorosis virus infecting Capsicum annuum in the east kimberley region of western Australia. Australasian Plant Pathology. 34: 397-399.

Kataoka, J., N. Habuka, M. Miyano, C. Masuta and A. Koiwai, 1992. Adenine depurination and inactivation of plant ribosomes by an antiviral protein of Mirabilis jalapa (map). Plant molecular biology. 20: 1111-1119.

Kaur, I., S. K. Yadav, G. Hariprasad, R. Gupta, A. Srinivasan, J. K. Batra and M. Puri, 2012. Balsamin, a novel ribosome-inactivating protein from the seeds of balsam apple Momordica balsamina. Amino acids. 43: 973-981.

Loebenstein, G. and G. Thottappilly, 2013. Virus and virus-like diseases of major crops in developing countries. Springer Science \& Business Media.

McCormick, S., J. Niedermeyer, J. Fry, A. Barnason, R. Horsch and R. Fraley, 1986. Leaf disc transformation of cultivated tomato (L. esculentum) using Agrobacterium tumefaciens. Plant Cell Reports. 5: 81-84.

Murugan, R., 1999. Characterization and mechanism of action of antiviral principles in Bougainvillea spectabilis Willd. M.Sc. Thesis, Tamil Nadu Agrl. Univ, Coimbatore

Öktem, H. A., Y. Bülbül, E. Öktem and M. Yücel, 1999. Regeneration and Agrobacterium-mediated transformation studies in tomato (Lycopersicon esculentum miller). Turkish Journal of Botany. 23: 345-348.

Pawar, B., A. Jadhav, A. Kale, V. Chimote and S. Pawar, 2012. Zeatin induced direct in vitro shoot regeneration in tomato (Solanum lycopersicum L.). The Bioscan. 7: 247-250.

Picó, B., M. J. Díez and F. Nuez, 1996. Viral diseases causing the greatest economic losses to the tomato crop. Ii. The tomato yellow leaf curl virus-a review. Scientia Horticulturae. 67: 151-196.

Poyet, J.-L., J. Radom and A. Hoeveler, 1994. Isolation and characterization of a cdna clone encoding the pokeweed antiviral protein ii from Phytolacca americana and its expression in e. Coli. FEBS 
letters. 347: 268-272.

Rajesh, S., R. Balasaraswathi, S. Doraisamy and S. Sadasivam, 2005. Synthesis and cloning of cDNA encoding an antiviral protein from the leaves of Bougainvillea spectabilis willd.(Nyctaginaceae). World Journal of Agricultural Sciences. 1: 101-104.

Roselló, S., M. J. Díez and F. Nuez, 1996. Viral diseases causing the greatest economic losses to the tomato crop. I. The tomato spotted wilt virus-a review. Scientia Horticulturae. 67: 117150.

Sadasivam, S., S. Rajamaheswari and R. Jeyarajan, 1991. Inhibition of certain plant viruses by plant extracts. Journal of Ecobiology. 3: 53-57.

Sambrook, J., E. F. Fritsch and T. Maniatis, 1989. Molecular cloning: A laboratory manual. Cold spring harbor laboratory press.

Sastry, K. S., 2013. Impact of virus and viroid diseases on crop yields. In: Plant virus and viroid diseases in the tropics. Springer: pp: 99-159.

Smith, T., R. Jones and S. Wylie, 2006. Genetic diversity of the nucleocapsid gene of iris yellow spot virus. Australasian Plant Pathology. 35: 359362.

Stirpe, F., D. G. Williams, L. J. Onyon, R. F. Legg and W. A. Stevens, 1981. Dianthins, ribosome-damaging proteins with anti-viral properties from Dianthus caryophyllus 1.(carnation). Biochemical journal. 195: 399-405.

Susumu, K., T. IKEDA, S. IMAIZUMI, Y. TAKANAMI and Y. MIKAMI, 1990. A potent plant virus inhibitor found in Mirabilis jalapa 1. Japanese Journal of Phytopathology. 56: 481-487.

Tumer, N. E., D.-J. Hwang and M. Bonness, 1997. C-terminal deletion mutant of pokeweed antiviral protein inhibits viral infection but does not depurinate host ribosomes. Proceedings of the National Academy of Sciences. 94: 3866-3871.

Van Damme, E. J., A. Barre, P. Rougé, F. Van Leuven and W. J. Peumans, 1997. Isolation and molecular cloning of a novel type 2 ribosome-inactivating protein with an inactive $b$ chain from elderberry (Sambucus nigra) bark. Journal of Biological Chemistry. 272: 8353-8360.

Vidya, C. S., M. Manoharan, C. R. Kumar, H. Savtthri and G. L. Sita, 2000. Agrobacterium-mediated transformation of tomato (Lycopersicon esculentum var. Pusa ruby) with coat-protein gene of physalis mottle tymovirus. Journal of plant physiology. 156: 106-110.

Vipul, B., 2003. Cloning and characterization of cDNA encoding an antiviral protein from Bougainvillea spectabilis Willd. M.Sc. Thesis, Tamil Nadu Agrl. Univ, Coimbatore

West, J. S., J. A. Townsend, M. Stevens and B. D. Fitt, 2012. Comparative biology of different plant pathogens to estimate effects of climate change on crop diseases in europe. European Journal of Plant Pathology. 133: 315-331.

Wu, Z., S. Sun, F. Wang and D. Guo, 2011. Establishment of regeneration and transformation system of Lycopersicon esculentum microtom.

\section{How to cite this article:}

Mayur R. Wallalwar and Balasaraswathi, R. 2017. Cloning and Transformation of Engineered Bougainvillea Antiviral Gene in Tomato Plant. Int.J.Curr.Microbiol.App.Sci. 6(6): 1714-1722. doi: https://doi.org/10.20546/ijcmas.2017.606.199 